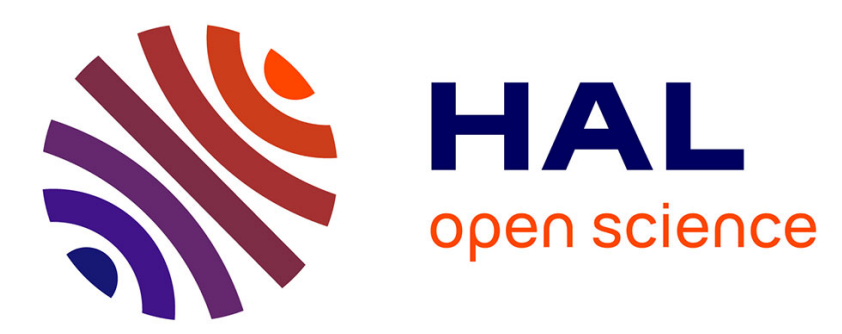

\title{
Low energy electrons and ultra-soft X-rays irradiation of plasmid DNA. Technical innovations
}

Michel Fromm, Omar Boulanouar

\section{To cite this version:}

Michel Fromm, Omar Boulanouar. Low energy electrons and ultra-soft X-rays irradiation of plasmid DNA. Technical innovations. Radiation Physics and Chemistry, 2016, 128, pp.44 - 53. 10.1016/j.radphyschem.2016.05.025 . hal-03558190

\section{HAL Id: hal-03558190 https://hal.science/hal-03558190}

Submitted on 4 Feb 2022

HAL is a multi-disciplinary open access archive for the deposit and dissemination of scientific research documents, whether they are published or not. The documents may come from teaching and research institutions in France or abroad, or from public or private research centers.
L'archive ouverte pluridisciplinaire HAL, est destinée au dépôt et à la diffusion de documents scientifiques de niveau recherche, publiés ou non, émanant des établissements d'enseignement et de recherche français ou étrangers, des laboratoires publics ou privés. 
See discussions, stats, and author profiles for this publication at: https://www.researchgate.net/publication/303667861

\section{Low energy electrons and ultra-soft X-rays irradiation of plasmid DNA.}

Technical innovations

Article in Radiation Physics and Chemistry · May 2016

DOI: $10.1016 /$ j.radphyschem.2016.05.025

CITATIONS

4

2 authors, including:

Michel Fromm

University of Franche-Comté

138 PUBLICATIONS 1,859 CITATIONS

SEE PROFILE
READS

224

Some of the authors of this publication are also working on these related projects:

Project $\quad$ Exposure of nanometre-scaled plasmid DNA layers to LEEs and plasmids exposed to USXs in aqueous media View project 


\title{
Low energy electrons and ultra-soft X-rays irradiation of plasmid DNA. Technical innovations.
}

\section{Michel Fromm and Omar Boulanouar}

${ }^{1}$ UMR CNRS 6249 Chrono-Environnement, Université de Bourgogne - Franche-Comté, 16 Route de Gray, F-2530 Besançon cedex.

\begin{abstract}
:
In this paper we present in a first part the latest results of our group which are in relation with the study of DNA damages inflicted by low energy electrons $(0-20 \mathrm{eV})$ in ultra-high vacuum as well as in air under atmospheric conditions. A short description of the drop-casting technique we developed to produce thin and nanometre-scaled DNA layers onto graphite sheets is given. We provide the absolute cross-section for loss of supercoiled topology of plasmid DNA complexed with 1,3diaminopropane (Dap) in the vacuum under $10 \mathrm{eV}$ electron impact and suggest a specific pathway for the dissociation of the transient negative ion formed by resonant capture of such a low energy electron (LEE) by the DNA's phosphate group when complexed to Dap. Well-gauged DNA-Dap layers with various nanometre-scaled thicknesses are used to evaluate the effective attenuation length of secondary photo-LEEs in the energy range (0-20 eV). The values of 11-16 nm for DNA kept under atmospheric conditions are in good agreement with the rare literature data available and which are stemming from computer simulations. In a second part, we describe the method we have developed in order to expose liquid samples of plasmid DNA to ultra-soft X-rays (Al K $\alpha$ line at $1.5 \mathrm{keV}$ ) under hydroxyl radical scavenging conditions. We provide an experimentally determined percentage of indirect effects in aqueous medium kept under standard conditions of $94.7 \pm 2.1 \%$ indirect effects; in satisfactory agreement with the data published by others (i.e. $97.7 \%$ ) relative to gamma irradiation of frozen solutions (Tomita et al., 1995).
\end{abstract}

Corresponding Author: Michel Fromm, michel.fromm@univ-fcomte.fr, Tel: (0) 33381666 560, Fax: (0) 33381666522

Keywords: Low Energy Electrons, effective attenuation length, Ultra-soft X-rays, diamines, amino acids, indirect effects. 


\section{Introduction}

Studying the mechanisms which engender ionizing radiation-induced DNA damages as well as suggesting a description of their exact nature is of topical interest in radiation biology and oncology (Lomax et al., 2013). Since the early developments of quantum mechanics by Hans Albrecht Bethe (Bethe, 1933), it is established that during its slowing-down in molecular hydrogen, a $1 \mathrm{MeV}$ electron produces a distribution of secondary electrons among which $77 \%$ have kinetic energies lower than $13.54 \mathrm{eV}$, while at $1 \mathrm{keV}, 68.8 \%$ of them have energies lower than $13.54 \mathrm{eV}$. Not so long ago, it was shown by using Monte Carlo simulations (Cobut et al., 1998) that over the whole set of secondary electrons generated in water in the track of a $150 \mathrm{keV}$ electron (or a proton having a kinetic energy of some $\mathrm{MeV}$ ), $50 \%$ have an energy less than $7.34 \mathrm{eV}$ (the threshold for electronic excitations in water (Michaud et al., 1991), 56\% have an energy less than $8.76 \mathrm{eV}$, the ionization energy of water, while $70 \%$ of these secondary electrons have energies which remain lower than $20 \mathrm{eV}$. The quantitative importance of such low energy electrons (LEEs) in the radiolysis of liquid water was also recently described in much detail (Pimblott and LaVerne, 2007). In the year 2000, the Sanche group published a paper in which they demonstrated experimentally that LEEs are capable of breaking DNA strands in the energy range [0-15] eV by dissociative electron attachment, DEA, (Boudaiffa et al., 2000). Consequently, it appears as an obvious experimental constraint that refined studies of the mechanisms at the beginning of ionizing radiation-induced DNA damage as well as measurements of their yields require that experiments might be conducted under ultra-high vacuum (HUV); especially due to the short order of magnitude of the LEEs attenuation lengths in condensed matter, especially in DNA (Tanuma et al., 1993), (Tan et al., 2005), (Emfietzoglou et al., 2009). Hence, when using the plasmid relaxation assay to quantify DNA strand breaks (Spotheim-Maurizot et al., 1990), solid DNA sample preparation might be carried out very carefully in order to ensure that thin layers are of uniform thickness and that such target layers will later be soluble in water without dramatic modification of their initial supercoiled proportion. It has in fact been shown that thin DNA plasmid layers deposited on metallic surfaces by means of freeze-drying technique may be of non-uniform thickness and might not be used without stabilizers being added to the sample before the evacuation process (Śmiałek et al., 2010). If electrochemical release of nucleic acids from electrode surfaces has been well-studied for gene delivery applications (Wang, 2011), a literature survey shows that nonelectrochemical deposition methods are in fact rather rare. It can for example be found that 2-D densely packed ordered nanostructures can be made by using DNA complexed with poly(amidoamine) (PAMAM) dendrimer, the layer being formed by drop-casting an aqueous solution containing positively overcharged complexes onto mica (Su et al., 2007). Unfortunately, such a method allows neither easy re-suspension in water nor LEE irradiation experiments as mica is an 
insulator (the substrate is also the electrode when performing LEE bombardment in HUV). By using a simple soft adsorption process (drop casting), we have shown that the affinity of doubly-charged, 1-3 diaminopropane $\left(\mathrm{Dap}^{2+}\right)$ for DNA permits the growth on highly oriented pyrolytic graphite (HOPG) substrates, of plasmid DNA films, of known uniform thickness (Boulanouar et al., 2011). Furthermore, such nanometre scaled and well-gauged layers have been designed to erode in water with a minimum loss of supercoiled topology provided that Tris buffer is present in the mother solution. We will shortly recall how such ultra-thin layers enabled the absolute cross section for a DNA single strand break to be measured at the resonance energy of $10 \mathrm{eV}$ (Boulanouar et al. 2013a), due to DEA. Similar layers but in which Tris buffer is absent where used as probes for electron stimulated desorption experiments (ESD) in the energy range 0-20 eV (Boulanouar et al., 2013b). Anion desorption yields for the mass ratios $17 / 16$, namely $\mathrm{OH}^{-} /\left[\mathrm{O}^{-} / \mathrm{NH}_{2}{ }^{-}\right]$, were analysed because they appeared to be significantly different from all other published data, indicating that the presence of $\mathrm{Dap}^{2+}$ in the close vicinity of the DNA molecule modulates ESD patterns. Armed with these experimental developments and using an original strategy first developed in order to expose DNA to LEEs in air (Brun et al, 2009), we used the ultra-soft X-ray-induced secondary-electron emission spectra of HOPG surfaces covered with various plasmid [DNA•Dap] thicknesses to estimate the mean attenuation length of LEEs (the emitted secondary photo-electrons) in DNA. But, in real biological situation, cellular DNA is wrapped around histone proteins and the whole structure is in bulk interaction with water molecules. In order to mimic as much as possible such a situation and keeping in mind that secondary-electron emission is limited in space when dealing with low energy electrons, we developed an experimental strategy that allows DNA irradiation in aqueous media at a nanometric level. The radiochemical yields for the production of reactive oxygen species in the radiolysis of water by ultra-soft Aluminum $\mathrm{K} \alpha$ line $(1.5 \mathrm{keV})$ photons are of the same order of magnitude than those of higher energy photons (Yamaguchi et al., 2005). It appears however that their relative spatial distributions within the radiation track are not equivalent. These distributions are in fact strongly correlated with the initial energy of the electromagnetic radiation. Differences in DNA damage yields observed experimentally finally do not arise from differences in initial $\mathrm{OH}$ radical yields but reflect differences in the number of $\mathrm{OH}$ radicals that become homogeneously distributed further to recombination (Fulford et al., 1999). This particular point is clearly illustrated in the work published by Watanabe and Saito (Watanabe and Saito, 2002) where Monte Carlo simulations evidence the very small volumes of water affected by secondary reactive species in the track of a 1 keV photon (in comparison with lower or higher energy photons). Thus, Al K $\alpha$ (1.5 keV) photon beams constitute a local probe that makes it possible to record data in aqueous media stemming from very local interaction volumes, namely spatial extensions of some tens of nanometres. 


\section{Materials and Methods}

\subsection{Chemicals}

Plasmid DNA (pUC21, 3266bp length and with a molecular weight of $2.13 \times 10^{6} \mathrm{Da}$ ) at an initial concentration of $1 \mathrm{mg} / \mathrm{mL}$ in water for injection (WFI) was obtained from Plasmid Factory GmbH \& Co. KG (Germany). Without further purification, stock solutions of this DNA (>95\% supercoiled) were prepared by dilution with ultrapure water having a resistivity of $18.2 \mathrm{M} \Omega \mathrm{cm}$. pBR322 plasmid (4361bp length and a molecular weight of $2.85 \times 106 \mathrm{Da}$ ) was purchased from TermoScientific (Thermo Fisher Scientific, France) it is isolated from E.Coli and purified by chromatography. In its initial form, the plasmid DNA had a measured supercoiled topology $\geq 98 \%$ and came at a concentration of $500 \mathrm{ng} / \mathrm{\mu L}$ suspended in storage buffer (10 mM Tris-HCl (pH 7.6) + $1 \mathrm{mM}$ EDTA). The stock solutions were stored at $-20^{\circ} \mathrm{C}$. DNA concentrations were determined by measuring the absorbance at $260 \mathrm{~nm}$ using the molar extinction coefficient $\varepsilon_{260}=5.3 \times 10^{7} \mathrm{~cm}^{-1} \mathrm{M}^{-1}$.

1,3-diaminopropane dihydrochloride ( $\geq 98 \%)$ also called Dap herein, and protonated basic amino acids of arginine hydrochloride $(\geq 98 \%)$, histidine hydrochloride $(\geq 98 \%)$, lysine hydrochloride $(\geq 98 \%)$ were all purchased from Sigma-Aldrich and kept at $4^{\circ} \mathrm{C}$. Solutions were freshly prepared before each experiment. To make the deposits, solutions of the plasmids of $40 \mathrm{ng} / \mu \mathrm{l}$ were mixed with an equal volume of a solution containing protonated ligands molecules to attain the desired ratios $\mathrm{R}$ at the molar concentrations of the cations to that of anionic phosphate moieties of plasmid DNA in the solution, i.e., $\mathrm{R}=[$ cation $] /\left[\mathrm{PO}_{4}{ }^{-}\right]=16$. Films were formed on HOPG (ZYA grade, NT-MDT) substrates according to the protocol described in an earlier paper (Boulanouar et al., 2011).

\subsection{Deposits}

We use a protocol which was described elsewhere in details (Boulanouar et al., 2011). In brief, a droplet of $50 \mu \mathrm{l}$ of the DNA- Ligand mixture was deposited onto a freshly cleaved graphite (HOPG, ZYA grade, NT-MDT) surface and incubated during $15 \mathrm{~min}$. Next, the surplus mixture solution was removed using filter paper. This protocol ensures a circular smear of constant diameter $8 \pm 1 \mathrm{~mm}$ to be created on the freshly cleaved HOPG surface. Then after, drying in clean air for 3 min was performed.

\subsection{AFM et XPS}

The AFM images were obtained with a Molecular Imaging scanning probe microscope (Agilent, USA). The topography of the surface could be recorded in air, at standard temperature and pressure, with silicon nitride tips coated with aluminium (Nanoandmore) at a resonant frequency of $300 \mathrm{kHz}$ in the tapping mode. The film thicknesses were determined by AFM. Scratching with the tip of the AFM in 
the contact mode makes a depression in the film, the depth of which corresponds to the film thickness, which are then measured in the tapping mode.

XPS analyses are described in details elsewhere (Boulanouar et al., 2013b), in brief, XPS measurements were performed in a UHV chamber at an operating pressure of $4 \times 10^{-10}$ Torr using a Perkin Elmer ESCA 4.0 XPS system equipped with a dual anode $(\mathrm{Mg} / \mathrm{A} 1)$ X-ray source $(\mathrm{P}=400 \mathrm{~W}$, Physical Electronics, 04-548), a hemispherical electron energy analyzer (Physical Electronics, 10-360), and a channeltron detector.

\subsection{Aqueous samples}

Prior to ultra-soft X-ray irradiation, the plasmid DNA stock solutions were diluted either in Tris or Arg, His or Lys aqueous solutions at different concentrations or only in ultra-pure water having a resistivity of $18.2 \mathrm{M} \Omega$ to obtain DNA solutions at final concentrations of $10 \mathrm{ng} \cdot \mathrm{\mu L}^{-1}$. The samples were kept on ice, before and after irradiation. Irradiation of $100 \mu \mathrm{L}$ of plasmid aqueous solution was performed using a cylindrical 8-mm-diameter sample holder, the aqueous solution being $2 \mathrm{~mm}$ thick. As demonstrated in a recent paper (Souici et al., 2016), when using such low volumes, stirring is essential to ensure a homogeneous dose deposition.

\subsection{Low energy electrons, electron stimulated desorption and lonizing radiations}

Exposure of the plasmid layers to low energy electrons was performed as mentioned in two earlier references of the Sanche group (Boudaïffa et al., 2002) (Panajotovic et al., 2006) and as briefly detailled in a recent paper (Boulanouar et al., 2013a). Electron stimulated desorption experiments were performed in the laboratory of $\operatorname{Pr}$ Sanche at the Sherbrooke university, a complete description of the experimental protocol can be found in a recent paper (Boulanouar et al., 2013b). The ultra-soft $\mathrm{X}$-rays used for plasmid irradiation were generated with a cold-cathode source (1.5 keV, Al K $\alpha$ ); the lab-bench cold cathode X-ray generator was described in detail elsewhere (Ounoughi et al., 2013). The complete irradiation protocol as well as the Fricke dosimetry process also were described recently elsewhere (Souici et al., 2016).

\subsection{Plasmid relaxation assay}

The experimental procedure was described in details elsewhere. As for the plasmid relaxation assay applied to solid deposits (layers) dissolved in water, the reader should refer to (Boulanouar et al., 2011) and (Boulanouar et al., 2013a), for liquid samples, see (Souici et al., 2016). 


\section{Low Energy Electrons and dry deposits}

Nanometre-scaled layers containing pUC21 plasmid DNA complexed with diaminopropane (Dap $\left.{ }^{2+}\right)$ have been characterized by means of atomic force microscopy (AFM) and X-ray photoelectron spectroscopy (XPS). AFM studies have both demonstrated that layers deposited onto freshly cleaved highly oriented pyrolytic graphite (HOPG) sheets are of uniform thickness and that at a fixed $\mathrm{R}$ value (the DNA/Dap mixing ratio, $\left.\mathrm{R}=\left[\mathrm{Dap}^{2+}\right] /\left[\mathrm{PO}_{4}{ }^{-}\right]_{\mathrm{DNA}}\right)$, the measured thickness appears to be strongly correlated with the initial DNA concentration in the drop deposited on the surface (Boulanouar et al., 2011). We show that at fixed mixing ratio, the mean thickness of a layer is linked to the DNA concentration by a monotonic and increasing relation (Fig. 1). Such highly organised DNA films in which DNA plasmids are complexed with 1,3-diaminopropane are suitable for quantitative LEE irradiation studies. The Dap molecule which is doubly ionized at neutral pH binds to the anionic phosphate moieties of the DNA double helix (Korolev et al., 2004a), (Korolev et al., 2004b) but also binds plasmid DNA molecules to HOPG and to each other (Boulanouar et al., 2011).

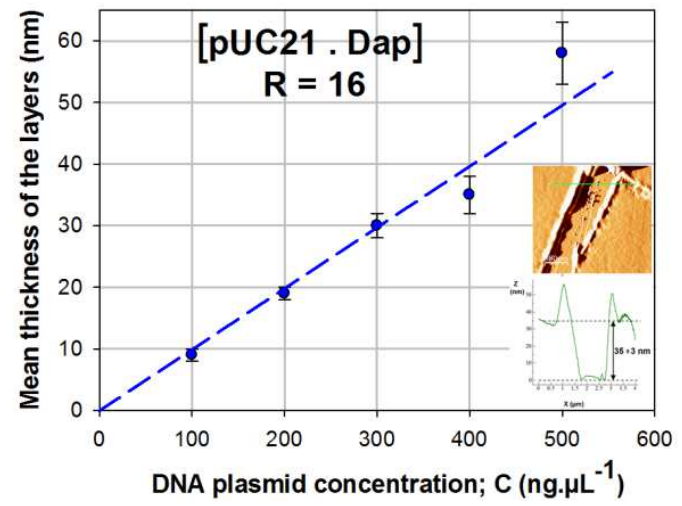

Figure 1 : AFM data showing the dependence of the mean layers thickness of DNA-Dap complexes on HOPG as a function of the initial concentration of plasmid DNA, this concentration stands for a fixed mixing ratio $\mathrm{R}=16$. The dashed line is only drawn to guide the eye. Error bars are the standard deviations obtained for at least three measurements. The inset shows an AFM picture corresponding to the measurement of the thickness ( $35 \pm 3 \mathrm{~nm}$ ) of a sample which belongs to the data set used to determine the mean value of the point at $C_{D N A}=400 \mathrm{ng} \cdot \mathrm{LL}^{-1}$.

Significantly, all but the first monolayer of such films (which is tightly bound to the substrate and whose thickness is measured equal to $2.2 \pm 1 \mathrm{~nm}$ ) can be removed by washing for post-irradiation analysis (Boulanouar et al., 2011). As an initial assessment of the effects of LEEs on DNA/Dap ${ }^{2+}$ complexes, multiple samples of 10 monolayers, (ML) with $22 \mathrm{~nm}$ thickness were irradiated at an electron current of $5 \mathrm{nA}$ for periods of $90 \mathrm{~s}$, at energies of between 3.5 and $13.5 \mathrm{eV}$. The data showed a dramatic loss of SC DNA at electron energies near $10 \mathrm{eV}$ (Boulanouar et al., 2013a). This result is consistent with the earlier results of Boudhaiffa et al. (Boudaiffa et al., 2000). Subsequent theory (Barrios et al., 2002), (Li et al., 2003) and experiment, (Zheng et al., 2005) have attributed strand 
breaks at these electron energies to DEA; a process in which an incident electron is captured by a molecule to form a transient molecular anion (TNI) that subsequently (typically within $\sim 10^{-13} \mathrm{~s}$ ) dissociates into neutral and anionic fragments. Interestingly, in contrast to the earlier results (Boudaiffa et al., 2000) (Boudaiffa et al., 2002) double strand breaks were not observed. It is noteworthy here to note that due to the high quality of the samples used (homogeneity and well defined thickness), the irradiation experiments were conducted using much lower electron current densities (a tenfold ratio) as those used in previous experiments of the Sanche group. In the present experiments, the layers were exposed to $0.39 .10^{12}$ electrons. $\mathrm{s}^{-1} \cdot \mathrm{cm}^{-2}$ and the time required to reach the plateau (data is expressed in \% of supercoiled plasmid DNA as a function of "dose") was 8 minutes as in the experiments of Boudaiffa and co-workers (Boudaiffa et al., 2002) the current density was set to $4.10^{12}$ electrons. $\mathrm{s}^{-1} \cdot \mathrm{cm}^{-2}$ and the time required to reach the plateau was greater than 60 minutes. Such a difference in both current density and exposure time that lower the total number of incident electrons a hundredfold is in favour of the insignificant rate of DSBs observed in the present experiments. We performed cross section measurements for electron induced single strand-break damage at $10 \mathrm{eV}$, to plasmid DNA samples prepared by the above-mentioned method. These measurements were obtained using films of three different thicknesses, namely films of $5 \mathrm{ML}$ (11nm), 7.5 ML (16.5 nm) and $10 \mathrm{ML}(22 \mathrm{~nm})$ thickness; a monolayer is considered to be equivalent to a $2.2 \mathrm{~nm}$ thickness. In the present experiments, the large decrease under irradiation in the percentage of SC DNA (Boulanouar et al., 2013a) indicates that these DNA/Dap ${ }^{2+}$ films charge much less than what was observed in previous investigations by the Canadian group of Pr. Leon Sanche, where high-purity and lyophilised samples have been used. It appears also likely that electrons propagate and induce damage throughout much of the DNA/Dap ${ }^{2+}$ films. Indeed, it was apparent by inspection of the experimental data (Figure 3 of Boulanour et al., 2013a) that the three exposure response curves were remarkably similar, indicating that the attenuation length in these experiments is greater than the range of film thicknesses studied. The dose response data obtained in that study is thus analysed to determine a cross section for the loss (or transformation) of SC DNA/Dap ${ }^{2+}$ complexes under electron irradiation at $10 \mathrm{eV}$ using methods similar to the "Molecular Survival Model" (Rezaee et al., 2012). Based on the assumption that the current density $J(x)$ varies exponentially with penetration depth $x$, namely $J(x)=J_{0} \times \exp -x / \lambda$, the following relation (Rezaee et al., 2012) was demonstrated:

$$
\sigma_{\mathrm{SSB}}=\frac{\mathrm{P}^{\prime}(\mathrm{t} \approx 0)}{\mathrm{P}_{0} \mathrm{~J}_{0}\left(\frac{\lambda}{\mathrm{h}}\right)\left(1-\mathrm{e}^{-\frac{\mathrm{h}}{\lambda}}\right)}
$$


In relation (1), $\mathrm{P}^{\prime}(\mathrm{t})$ is the proportion of undamaged plasmid DNA extrapolated at the dose zero, $\mathrm{P}_{0}$ is that same proportion but taken before the experiments have been started (i.e. 96,1\%), $\lambda$ stands for the attenuation length of the LEEs at $10 \mathrm{eV}$ in the sample and $\mathrm{h}$ is equal to the thickness of the removable fraction of the layers, namely the total thickness to which a constant value of $2.2 \mathrm{~nm}$ must be subtracted. Multiple fitting sessions based on a Levenberg-Marquardt algorithm (LMA) enabled the values of the absolute cross section $\sigma$ and of the attenuation length $\lambda$ to be optimized. The mean cross section $\sigma$ for loss of SC-form (and its conversion into the C-state) is $(3.0 \pm 0.3) \times 10^{-14} \mathrm{~cm}^{2}$ at 10 $\mathrm{eV}$ while $\lambda$ was determined to be $(14.1 \pm 5.4) \mathrm{nm}$. With a number of 3266 base pairs in a pUC21 plasmid, the resulting cross section expressed per base, $\sigma_{b}$, has a value of $(4.6 \pm 0.5) \times 10^{-18} \mathrm{~cm}^{2}$, this latter can be compared to that measured in lyophilized samples of varying thickness, of pure DNA (plasmid pGEM-3Zf(-), 3197 bp), i.e. $(5.9 \pm 1.9) \times 10^{-18} \mathrm{~cm}^{2}$ (Rezaee et al., 2012). It can thus be considered that the absolute cross section for SC-form loss is essentially similar for pure DNA plasmids and for the DNA/Dap ${ }^{2+}$ complexes (we evaluate a variation of $22 \%$ ). Interestingly, all normalized total DEA cross sections for the DNA bases thymine, cytosine, and adenine and for three compounds used as surrogates for the ribose and phosphate groups calculated using the binaryencounter-Bethe method (Aflatooni et al., 2006) are confined in the $[0.18-7.1] \times 10^{-19} \mathrm{~cm}^{2}$ interval. The attenuation length $\lambda$ determined with layers composed of DNA/Dap ${ }^{2+}$ complexes, namely $(14.1 \pm$ 5.4) $\mathrm{nm}$, is somewhat larger than the one found by examination of lyophilized samples (10.4 \pm 5.4$)$ nm (Rezaee et al., 2012). It was reported that charging of lyophilized films happened during experiments and that such films may have highly non-uniform thickness and surface density (Śmiałek et al., 2011) that limit LEE penetration and thus, only a small percentage of the sample $(<10 \%)$ is exposed to electrons. It is finally unsurprising to find a longer $\lambda$ in the absence of severe charging, and additionally, AFM images (Boulanouar et al., 2013a) prove that if uniform, DNA/Dap ${ }^{2+}$ films exhibit rather large porosity (nanometric holes are present inside these films) which in turn might favour easier LEEs travel through larger thicknesses.

The surprising absence of DSBs and its relationship to the presence of $\mathrm{Dap}^{2+}$ raise the question of the impact of DNA's close environment on its damaging mechanism. It is possible that the presence of $\mathrm{Dap}^{2+}$ perturbs in some way electron transfer, this latter being believed to be required for the induction of DSB by LEEs and TNIs (Li et al., 2011). In order to verify this assumption, we investigated the specific features of LEE irradiation of the complex formed between plasmid DNA and Dap ${ }^{2+}$ by examination of the dissociative processes leading to the direct desorption of anionic species (Boulanouar et al., 2013b). DNA-Dap films auto-assembled on HOPG with molar ratios $R=$ $\left[\mathrm{Dap}^{2+}\right] /\left[\mathrm{PO}_{4}^{-}\right]_{\mathrm{DNA}}=8,16$, and 32 , have been prepared with $\mathrm{C}_{\mathrm{DNA}}=20 \mathrm{ng} / \mu \mathrm{l}$ so that the films have respectively thicknesses of $(4,7$, and 10$) \pm 1 \mathrm{~nm}$, as measured on at least three samples for each ratio. Those films have first been analysed by XPS in order to get an estimate of the mean number of 
$\mathrm{Dap}^{2+}$ molecules per base pair present in the deposits, namely by determining the excess of nitrogen in comparison with $(\mathrm{N} / \mathrm{P})_{\mathrm{DNA}}=3.75$, the ratio of Nitrogen to Phosphorous of the DNA plasmids used in this study. This (excess) number is determined equal to $1.27,1.75$ and 1.63 respectively (see Fig. 2) for the samples with 4,7 , and $10 \mathrm{~nm}$ thickness.

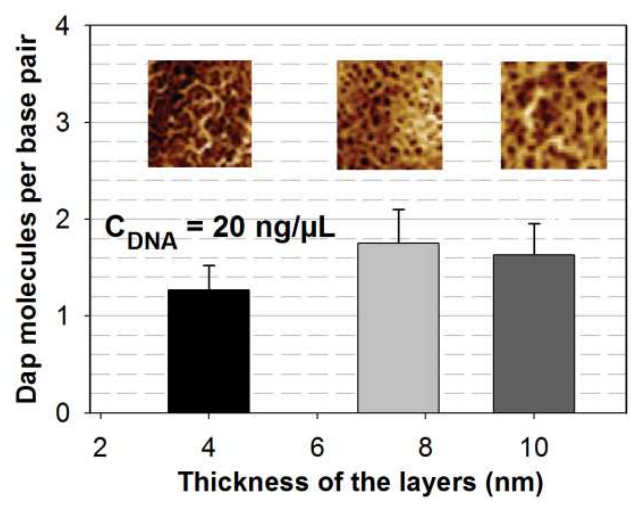

Figure 2: XPS-estimated composition of three layers with different thicknesses expressed in number of Dap molecule per base pair of pUC21 plasmid DNA. The three insets are AFM snapshots with an image scale of $1.5 \times 1.5 \mu \mathrm{m}$.

XPS precision (in atomic percent) is known to be accurate within $\sim 10 \%-20 \%$ depending on the particular depth distribution of the atoms (Tougaard, 2013). The present XPS data shows that there is an excess of Dap molecules in the layers and thus that the DNA phosphate moieties might be associated in majority with amino terminal groups of the Dap diamines. Interestingly, the layer for which the proportion of excess Dap is the highest (the sample with a $7 \mathrm{~nm}$ thickness), is also the one for which the desorption rate of the mass ratio $\mathrm{OH}^{-} /\left[\mathrm{O}^{-} / \mathrm{NH}_{2}{ }^{-}\right]$is the greatest (namely 3.5). Without going here into complete details, all the published studies, which all deal with anion ESD of DNA layers produced by lyophilisation (i.e., layers containing no amino groups, except the possible presence of small proportions of the Tris buffer), show ratios $<1$. This is in contradiction with the case of our samples for which this mass ratio $17 / 16\left(\mathrm{OH}^{-} /\left(\mathrm{O}_{2}{ }^{-} / \mathrm{NH}_{2}{ }^{-}\right)\right)$, ranges from 1.65 up to 3.5. The presence of large amounts of diamines, which for their major part are complexed to the DNA phosphate moieties, should be responsible for such unexpected high ratios. This suggests a mechanism of the transient negative ion (TNI) dissociation involving the loss of a hydroxyl anion instead of an $\mathrm{O}^{-}$anion; this latter, actually being generally detected when "pure" DNA layers are subjected to ESD. To explain this we propose that the dissociative state of the TNI formed by the capture of an electron by the DNA's phosphate group has a longer lifetime than the time required for a proton transfer (Boulanouar et al., 2013b). In such conditions, an OH moiety can be formed by transfer of the labile proton of the ammonium moiety $\left(\mathrm{Dap}^{2+}\right)$ during the lifetime of the resonance. We have thus reasons to believe that the close environment of DNA in living species may modify the fragmentations pathways resulting from dissociative electron attachment in real biological situation. 
If the $\mathrm{OH}^{-} /\left[\mathrm{O}^{-} / \mathrm{NH}_{2}{ }^{-}\right]$ratio is an indicator of the specific dissociative channels involved in TNI decay within any DNA layer's chemical composition, we showed also that the $\mathrm{O}^{-} / \mathrm{NH}_{2}^{-}$yields (i.e. as demonstrated therein these yields are essentially due to $\mathrm{NH}_{2}^{-}$) are directly proportional to the ratios (diamines/bp) in the samples, as verified by XPS analyses (Boulanouar et al., 2013b).

But these entire results stem from experiments realized in UHV and may therefore be questioned, notably due to the absence of water. Exposing DNA to LEEs in atmospheric conditions constitute in fact a real challenge, especially due to the very short penetration distances of LEEs in matter.

\section{LEE mean effective attenuation length in DNA as measured under atmospheric conditions}

In the year 2009, a pioneering work was published (Brun et al., 2009) which demonstrated the feasibility of exposing thin lyophilized DNA layers to LEEs in air. The cunning technique used to achieve this goal is actually based on the observation that thin nanometre-scaled layers of DNA are quasi-transparent to ultra-soft X-rays (USXs). USXs in turn, when absorbed in the substrate on which DNA is deposited, provoke the emission of a specific spectrum of secondary photoelectrons in the energy range 0-12 eV (Henke et al., 1977) with a maximum of the distribution lying near to some $\mathrm{eV}$ (Tantalum was used as a substrate in those early experiments). We have used this method to expose layers composed of DNA-Dap complexes of various gauged thicknesses to LEEs in air. In the present case, the substrate is composed of freshly cleaved HOPG foils. The USX source is the Al $\mathrm{K}_{\alpha}$ line (1.5 $\mathrm{keV}$ ) generated by using a lab-bench cold-cathode system (Ounoughi et al., 2013), with a well characterized beam, both spatially and energetically (Groetz et al., 2014), (Ounoughi et al., 2015). Deposits with thicknesses ranging from 10 to $200 \mathrm{~nm}$ have been exposed to increasing doses of $\mathrm{Al} \mathrm{K \alpha}$ USXs; therefore to various doses of LEEs. DNA layers are entirely exposed to X-rays; the diameter of the deposits is $8 \mathrm{~mm}$ and at the distance source-sample used $(10 \mathrm{~mm})$ this area can be considered as uniformly exposed to the photon beam (Ounoughi et al., 2013). The irradiation time was varied from 4 to 16 minutes. Within our experimental conditions, namely with the samples at $10 \mathrm{~mm}$ from the $\mathrm{X}$ ray source in air and using an accelerating voltage of $2 \mathrm{kV}$, the applied Kerma rate (i.e. measured in air using an ionization chamber) is $1.7 \mathrm{~Gy} / \mathrm{min}$ (Ounoughi et al., 2013). It should be noticed that within the protocol used for the deposition of auto-assembled DNA complexes on the surface of graphite (vide supra), when the thicknesses are greater than $50 \mathrm{~nm}$ the calibration of the thickness starts to be less precise. The thicknesses of 100 and $200 \mathrm{~nm}$ where indeed obtained by letting a drop of an aqueous DNA-Dap mixture with a calibrated concentration fully evaporate in air so that the matter that remains on the surface of the graphite foils must have heights that are close to the expected ones (those that simple calculation makes it possible to await). This is possible due to the fact that graphite has hydrophobic surface properties and thus, a drop of water with a fixed volume has a contact area on the HOPG surface that can reasonably be considered constant (we measured 
typically $8 \mathrm{~mm} \pm 1 \mathrm{~mm}$ for a drop of $50 \mu \mathrm{l}$ deposited on the freshly cleaved surface). For the two largest thicknesses, it was not possible to measure the height of the deposits using the AFM method described above. The thicknesses of 100 and $200 \mathrm{~nm}$ are thus estimates and it is quite reasonable to consider them as average values accompanied with large deviations (for these reasons, we set on a maximum of $\pm 25 \%$ of the average thickness). The DNA damages were determined and plotted as a function of USX exposure time which is a relative measure of LEE dose absorbed in the deposits. DNA damages are expressed in loss of \% supercoiling, as determined by agarose gel electrophoresis analyses of the deposits suspended in water after irradiation. The complete set of data gathered during these experiments is presented in Fig. 3. It appears clearly that the thicker the samples, the lower are DNA damage rates. DNA damage rate can here be expressed simply by determining the slopes of the straight lines in Fig. 3.

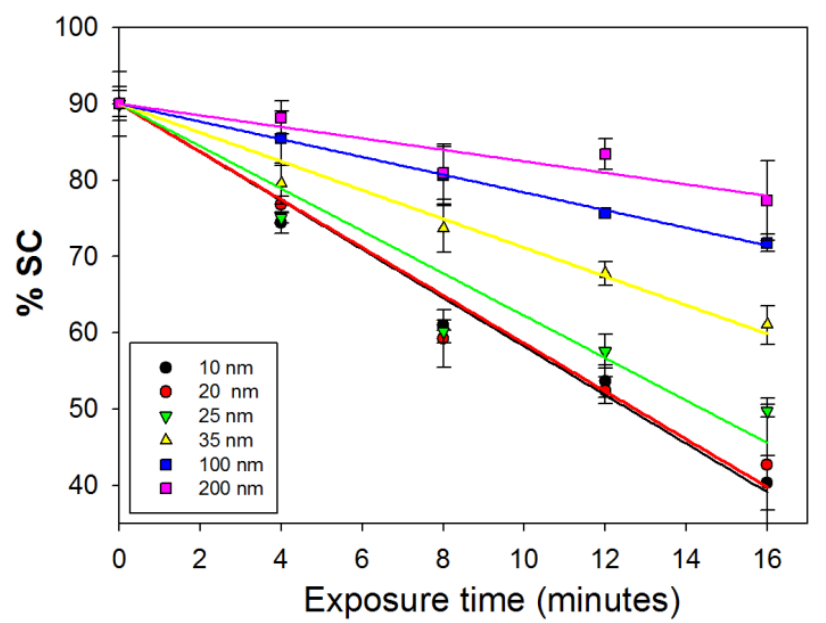

Figure 3: Evolution of the \% of supercoiled fraction (\%SC) of plasmid DNA deposited on HOPG with various thicknesses as a function of exposure time to the USX AI K $\alpha$ line. The straight lines are linear regressions realized on the experimental data (SigmaPlot ${ }^{\mathrm{TM}}$ ). Error bars are standard deviations of the average values of \%SC determined for at least three different samples.

A question that must be fixed here is: what is the exact cause of DNA damaging and more precisely, is there a source of damages that would be majority in comparison with all other possible sources of damages? A quick analysis of the problem shows that there are essentially three possible origins to DNA damaging by direct effect. The DNA layers are indeed steeped by the primary Al K $\alpha$ USXs (1.5 $\mathrm{keV}$ ) and, when absorbed in the HOPG substrate, the graphite foil acts in turn both as a C K $\alpha$ line $(0.28 \mathrm{keV})$ source and a LEE source (as will be shown later on herein, the maximum of the LEE distribution peaks near to $2 \mathrm{eV}$ ). In order to evaluate the potential of these three radiations in damaging DNA we compare their attenuation length in water, which is generally considered as being a good surrogate of DNA. Al K $\alpha$ and $C K \alpha$ attenuation lengths, $\lambda$, in water are quoted in a study

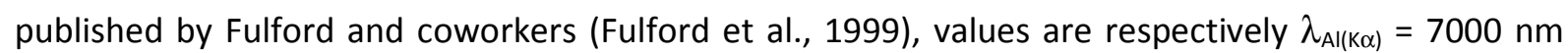
and $\lambda_{C(K \alpha)}=1800 \mathrm{~nm}$. As for the attenuation length of LEEs, available data for water (Emfietzoglou et 
al., 2009) stemming from calculations based on the dielectric electron-gas theory to which local-field corrections were applied render $7 \mathrm{~nm} \leq \lambda_{\mathrm{LEE}}(10 \mathrm{eV}) \leq 10 \mathrm{~nm}$. It is thus clear that the low energy electrons are absorbed in more than a hundred-fold proportion when compared to USXs of Carbon or Aluminium $\mathrm{K}$ lines. In order to make things clearer, an evaluation of the fraction of photons absorbed in water shows that for the $\mathrm{C} K \alpha$ line at $0.28 \mathrm{keV}$ which compared to the $\mathrm{Al} \mathrm{K} \alpha$ line has the highest mass attenuation coefficient, namely $\mu_{\mathrm{ck \alpha}}=5416 \mathrm{~cm}^{2} \cdot \mathrm{g}^{-1}$ (Fulford et al., 1999), the fraction of photons absorbed in a $200 \mathrm{~nm}$ thick layer of water reaches $10 \%$, this fraction drops down to $3 \%$ for the same thickness but when the Al K $\alpha$ line is used. Conversely, through a $10 \mathrm{~nm}$ thick layer of water, the C K $\alpha$ line will be transmitted at $99.5 \%$. Hence, it can be believed that most of the observed damages are due to LEEs, in the worst case ( $200 \mathrm{~nm}$ thick layers exposed to the $\mathrm{C} K \alpha$ line), solely $10 \%$ of the entire photon flux is absorbed. We measured the secondary photoelectron spectrum of HOPG under $\mathrm{Al} \mathrm{K} \alpha$ line irradiation in the range $7.5-65 \mathrm{eV}$ using and $\mathrm{X}$-ray photoelectron spectrometer. This spectrum is composed of a noisy region characterized by a weak yield for electron energies greater than $20 \mathrm{eV}$, on the other hand a sharp increase appears when dropping down to the low energies (typically $<20 \mathrm{eV}$ ). For technical reasons, unfortunately, it was not possible to measure the complete spectrum in that area, notably from 0 to $7.5 \mathrm{eV}$ where the signal appears to be an artefact (not shown here). Using the formula for the distribution of secondary photoelectrons emitted by metals provided by Henke and collaborators (Henke et al., 1977) in which we use the value of the work function of graphite (i.e. 4,47 eV), a tentative fit of the data at the low energies can be drawn (see Fig. 4, inset).

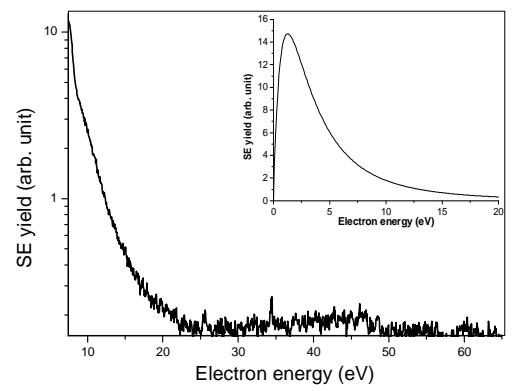

Figure 4: Experimentally determined yield (arbitrary units) of secondary photoelectrons emitted from graphite under Al K $\alpha$ line irradiation. The inset shows a tentative fit using the formalism proposed by Henke and collaborators (Henke et al., 1977). In this particular case the distribution reaches a maximum near to $2 \mathrm{eV}$.

We may thus describe our experiments in such a way that the DNA-Dap layers exposed to Al K X-rays will be subject to numerous LEE interactions, most of the LEEs having energies ranging from 0 to 20 $\mathrm{eV}$ with a major part of the energy distribution lying in a very low energy region $\sim(0-5 \mathrm{eV})$. Only a few percent of the damages is related to X-rays photoelectric absorption (Al and C K lines), especially for the thinner layers. We have determined the slopes of the straight lines in Fig. 3, namely their 
absolute values $|\mathrm{d}(\% \mathrm{SC}) / \mathrm{dt}|$, which constitute a measure of the total DNA damage rates expressed in terms of loss of supercoiled topology per unit time of irradiation (i.e. relative to the total irradiation dose).

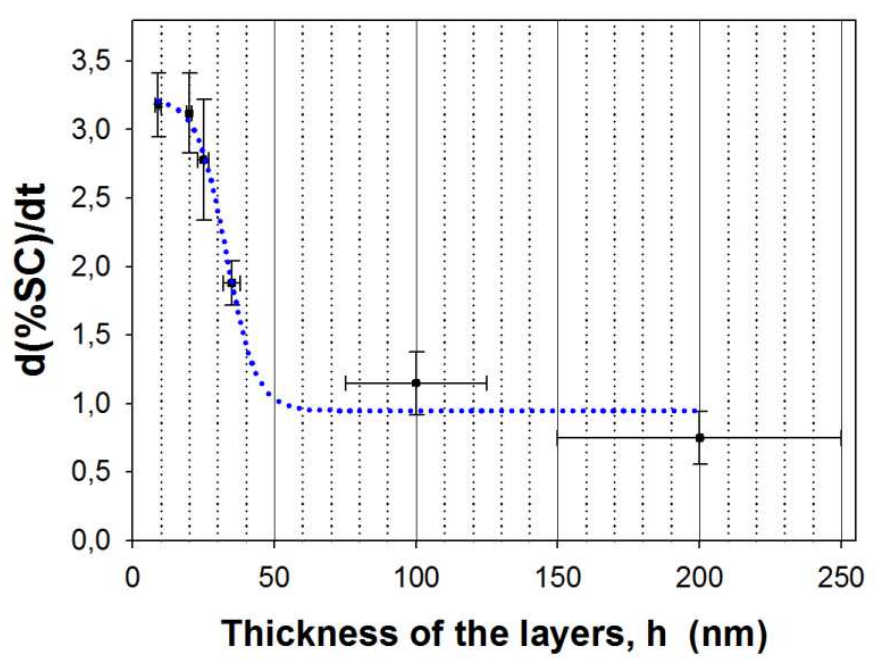

Figure 5: Experimentally determined damage rates as a function of layers mean height. Vertical error bars stand for the standard deviations of the linear fits realized on the data presented in Fig. 4. Horizontal error bars are those presented in Fig. 1 for $\mathrm{h}<50 \mathrm{~nm}$, when $\mathrm{h}>50 \mathrm{~nm}$, we fixed a $25 \%$ error (see text for more details). The dashed blue line is a logistic 4 parameters function, the goodness of fit is $\mathrm{R}^{2}=0.9840$.

When plotted versus layer's mean heights $(h)$ the experimental damage rates exhibit a sigmoidal trend (Fig. 5) which is fitted using the logistic 4-parameters function: $d(\% S C) / d t=a+b /(1+\exp (-(h-$ $\left.\left.h_{0}\right) / c\right)$ ), in that case the goodness of fit is $R^{2}=0.9840$ and $h_{0}=32.96 \pm 2.33 \mathrm{~nm}$ (the sigmoid's midpoint). Three distinct parts are clearly distinguishable, namely at the beginning a first short horizontal plateau followed by a sharp decrease of the damage rate starting from the $20 \mathrm{~nm}$ thickness up to a thickness value close to $50 \mathrm{~nm}$, thereafter the measured damage rates remain essentially independent of the thickness up to the largest thickness value (200 nm). In fact, for those two thicker layers, it seems that X-ray damaging is not sufficient to increase the measured damage rates (most of the DNA in the layers remains unexposed), but as the data for these two layers is soiled by large uncertainties, we focus our attention on the first part of the curve which correspond to the smaller thicknesses $(<50 \mathrm{~nm}$ ), those later being determined with much better accuracy (see Fig. 1). As mentioned above, with "small" thicknesses, the absorption of X-rays (both C and AI K lines) is essentially non-existent and therefore we might consider that resonant capture of low-energy secondary photoelectrons $(0-20 \mathrm{eV})$ is the main cause of loss of DNA supercoiling in that area (keeping nevertheless in mind that in this low-energy range, LEE elastic collisions, i.e. momentum transfer, is the dominant interaction). The upper limit of this area can be fixed to $50 \pm 10 \mathrm{~nm}$. By analogy with XPS practice, we might in a first glance see this value as an expanded estimate of the sampling depth of LEEs in DNA under atmospheric conditions (in a way a value close to the mean 
thermalization length of Carbon secondary photo-LEEs in DNA-Dap mixture under atmospheric conditions). In section 3, it was evidenced that for DNA-Dap layers with thicknesses 11, 16.5 and 22 $\mathrm{nm}$ exposed to $10 \mathrm{eV}$ LEEs under UHV the three exposure response curves were remarkably similar, indicating that the full range of LEEs is likely to be greater than the highest film thickness studied (i.e. $22 \mathrm{~nm})$.

The results presented in Fig. 5 being related to LEE irradiations performed under atmospheric conditions, it implies that the layers are likely to include hydration water in addition to Dap molecules. Regarding this particular aspect, it was recently suggested that internal diffraction can enhance the DNA damage probability, especially for electron energies below $15 \mathrm{eV}$ in hydrated DNA (Orlando et al., 2008). By contrast, if water must undoubtedly be present, it should nevertheless be mentioned that $\mathrm{Dap}^{2+}$ cations are prone to exclude water molecules from the close DNA backbone environment and particularly from the minor groove (Kielkpopf et al., 2000) (Korolev et al., 2004b). Moreover, the 3 methylene moieties of the Dap molecules (diaminopropane) are hydrophobic components which therefore might repel water in a certain way due to the important proportion of Dap in the layers (Fig. 2). Besides, experimental (Cai et al., 2006) and computed (Tan et al., 2006), (Emfietzoglou et al., 2009) determinations of attenuations lengths respectively in oligonucleotides or DNA layers exhibit an increase when LEE energies decrease (at energies $<100 \mathrm{eV}$ ), but attenuation lengths, $\lambda$, at energies lower than $10 \mathrm{eV}$ are neither easily measurable nor easily predictable.

The sharp decrease in damage rates observed in the range $20 \mathrm{~nm} \leq \mathrm{h} \leq 50 \mathrm{~nm}$ can be understood as a decrease of the number of LEEs capable of damaging DNA plasmids when the height of the layers increases (which is actually obvious within the concept of Beer-Lambert's law). Overall and considering this last remark, it seems pertinent to set on the full path length of LEEs (i.e. the sampling depth) to $50 \pm 10 \mathrm{~nm}$. According to the Beer-Lambert law as used in XPS analyses, the sampling depth is generally defined as the depth at which $95 \%$ of all photoelectrons have interacted; namely a distance of $3 \lambda$. In that way, $\lambda_{\text {air }}=50 / 3=16.7 \mathrm{~nm}$. This estimate is in line with the fact that within the sigmoidal character of the experimental curve, passing from a thickness $h=9 \mathrm{~nm}$ to $h=20 \mathrm{~nm}$ leads to respective damage rates 3.18 and $3.12\left(\% \mathrm{SC} \cdot \mathrm{min}^{-1}\right)$, equivalent to a very small relative variation of $2 \%$, while in passing from $h=20 \mathrm{~nm}$ to $\mathrm{h}=25 \mathrm{~nm}$, the relative variation of damage rate is $11 \%$ and passing from $25 \mathrm{~nm}$ to $35 \mathrm{~nm}$ the increase of thickness leads to a $32 \%$ relative variation of the damage rate. A more precise determination of the attenuation length of LEEs in DNA under atmospheric conditions seems difficult to obtain by this way due to the rather large uncertainties associated to the experiments and difficulties to reproduce easily several times exactly the same layer's thickness. We will thus consider that $\lambda \approx 16 \mathrm{~nm}$ is a consistent upper limit of the attenuation length of LEEs in DNA-Dap complexes under atmospheric conditions. Interestingly, in a recent paper (Suzuki et al., 2014), the effective attenuation length (EAL) of electrons with energies in the range 
[10-600] eV in liquid water was determined experimentally, additional data also are quoted stemming from references therein. The experimental data of electron EALs in liquid water exhibit rather flat energy dependence in the studied energy range, but EALs nevertheless exhibit a smooth increase when energy diminishes down to $5 \mathrm{eV} ; \mathrm{EAL} \approx 1.5 \mathrm{~nm}$ at $10 \mathrm{eV}$ and $\mathrm{EAL} \approx 3 \mathrm{~nm}$ at $5 \mathrm{eV}$. The penetration length of an electron with energy $10 \mathrm{eV}$ in water as determined by others (Uhera and Nikjoo, 2006) using Monte-Carlo simulations is $10 \mathrm{~nm}$, and the inelastic mean free path (IMFP) in liquid water computed from optical-data models of the Bethe surface (Emfietzoglou et al., 2012) is 10 $\mathrm{nm}$ at $10 \mathrm{eV}$. It should be noticed that IMFP should be greater that EAL, due to their respective definitions (Powell and Jablonski, 2002), (Suzuki et al., 2014). The EAL we estimate here in solid (but porous) DNA-Dap layers under atmospheric conditions is of the same order of magnitude than those we compare to. The value $\lambda \approx 16 \mathrm{~nm}$ seems to be a bit greater than the rare published data we have quoted. The value $\lambda \approx 16 \mathrm{~nm}$ is in fact an average value which is typically valid for LEEs in the energy range $[0-20 \mathrm{eV}]$, if this value is accepted, it would mean that the LEE component at the lower energies (i.e. $<5 \mathrm{eV}$ ) may have larger EALs than those which have been quoted in the literature and which remain in the order of magnitude of $10 \mathrm{~nm}$. Lastly, it may be clarified that $\lambda \approx 16 \mathrm{~nm}$ was here obtained on the base of a Beer-Lambert description of the absorption of LEEs by using $95 \%$ absorption (according to the definition of the sampling depth in the field of XPS). As LEEs are not emitted in a uniform manner and because we observe experimentally a plateau when the thicknesses become greater than $50 \mathrm{~nm}$ (see Fig. 5), it may not be senseless to set $99 \%$ absorption at $50 \mathrm{~nm}$ thickness; in that case we would get $\lambda \approx 11 \mathrm{~nm}$.

\section{Ultra-soft X-rays and aqueous DNA samples, scavenging $\mathrm{OH}$ radicals}

The effect of hydration water on DNA damage generated by photo-emitted LEEs was recently studied under atmospheric conditions (Alizadeh et al., 2013). In such a situation, indirect effects have to be taken into account owing to radiolysis of the hydration layer of DNA that becomes effective. Experiments in which only LEEs interact with DNA in aqueous solutions have not been performed in our knowledge, notably due to technical constraints associated with such an objective.

We have recently developed an experimental protocol which enables to expose small volumes (100 $\mu \mathrm{L}$ ) of plasmid DNA solutions to $1.5 \mathrm{keV} \mathrm{Al} \mathrm{K \alpha}$ USXs (Souici et al., 2016). In that case, of course, the DNA plasmids are not directly exposed to LEEs but to USXs, which as primary ionizing radiation, when absorbed in water produces secondary electrons of $0.96 \mathrm{keV}$ (photoelectron stemming from an oxygen atom) and a $0.52 \mathrm{keV}$ Auger-electron (Goodhead and Thacker 1977). The interesting point is that, in liquid water, such secondary electrons have typical mean penetration ranges of the order of $30 \mathrm{~nm}$ (Uehara and Nikjoo 2006) and along their trails; these electrons create large amounts of LEEs. 
In addition, when scavenging specifically reactive oxygen species (ROS) during water radiolysis it is possible to confine the action-distance of radicals to some nanometres (Souici et al., 2016 and references therein). The original technique based on USX irradiation of small and stirred volumes of water we developed is particularly relevant when there is a need to probing very local effects in aqueous environment and notably those arising at the scale of the nanometre and which are of central interest in modern radiation biology. In aerated aqueous solutions (i.e. solutions saturated with molecular oxygen), the intermediate products of radiolysis are ROSs of ${ }^{\circ} \mathrm{OH},{ }^{\circ} \mathrm{H}$ and $\mathrm{e}_{\mathrm{aq}}$ (the hydrated electron) which in contact with $\mathrm{O}_{2}$ form ${ }^{\circ} \mathrm{OH}, \mathrm{HO}_{2}$ and $\mathrm{O}_{2}{ }^{\circ-}$ these last species finally will stabilize to form $\mathrm{H}_{2} \mathrm{O}_{2}$ and $\mathrm{H}_{2}$ within typically $1 \mu \mathrm{s}$. Importantly, hydrogen peroxide alone or in other words, in the absence of metallic ions, is not able to damage DNA (Imlay et al., 1988). It is relevant here also to clarify that confining ROSs in space by using specific scavengers is equivalent to reduce the time laps during which these oxygenated species can interact within the medium. As an example, increasing the concentration of the specific ${ }^{\circ} \mathrm{OH}$ scavenger Tris, namely 2-amino-2-hydroxymethyl1,3-propanediol, from $1 \mathrm{mM}$ to $200 \mathrm{mM}$ is equivalent to a reduction of the hydroxyl radical mean diffusion distance from 82.52 to $5.84 \mathrm{~nm}$ (which amounts to reduce its mean lifetime from $667 \mathrm{~ns}$ to $3.33 \mathrm{~ns})$. We have studied the effect of such a space confinement of the $\mathrm{OH}$ radical in aqueous media by using pBR322 plasmid DNA as a probe $\left(C_{D N A}=10 \mathrm{ng} \cdot \mu^{-1}\right)$ and by measuring the single strand break yields (Souici et al., 2016) within the framework of the plasmid relaxation assay. The Al K $\alpha$ dose in aqueous media was determined by applying the absolute dosimetric method of Fricke. The concentration of the Tris scavenger varied as follows: $0.2,1,10,100$ and $200 \mathrm{mM}$.

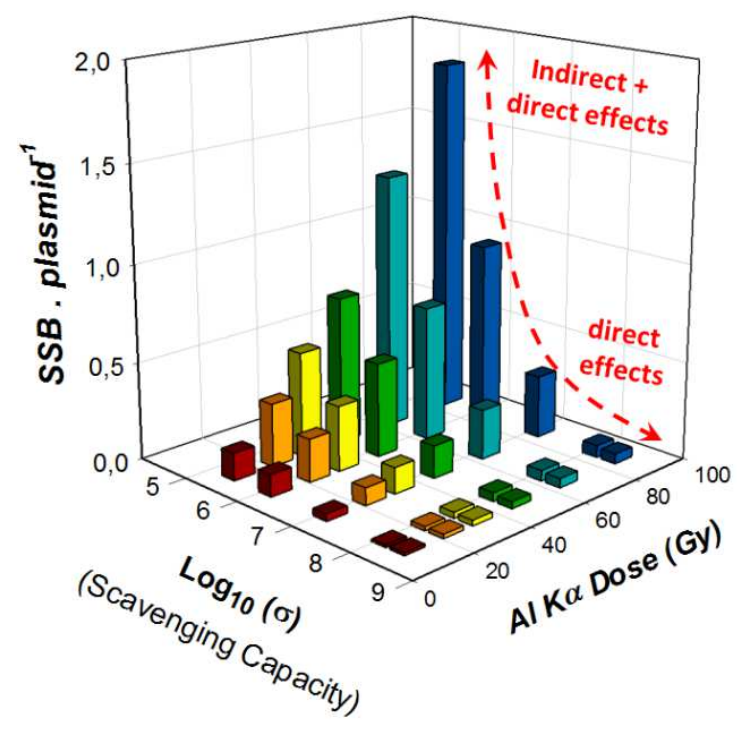

Figure 6: Experimentally determined damage rates of SSB per pBR322 plasmid as a function of both scavenging capacity of Tris and $\mathrm{Al} \mathrm{K \alpha}$ dose in aqueous solution. These results clearly reveal the asymptotic character of the SSB yield, namely a vertical asymptote at the low scavenging capacities and a horizontal asymptote at the high scavenging capacities (the red dashed line illustrates this asymptotic behaviour at the high doses). 
We present in Fig. 6 the evolution of the single strand break yield (plasmid ${ }^{-1}$ ) as measured versus both dose and scavenging capacity of Tris; $\sigma=\mathrm{k}$ [Tris] in $\mathrm{s}^{-1}$, where $\mathrm{k}$ stands for the hydroxyl radical scavenger reaction rate constant, namely $\mathrm{k}_{\text {Tris }}=1.510^{9} \mathrm{~L} \cdot \mathrm{mol}^{-1} \cdot \mathrm{s}^{-1}$ at $\mathrm{pH}=\sim 7$ (Hicks and Gebicki, 1986). The asymptotic character observed at both low and high scavenging capacities is nothing else than the signature of the separation of direct and indirect effects. It is indeed obvious that when the scavenging capacity tends to zero, both direct and indirect effects can freely take place. Conversely, at high scavenging capacities, owing to the effective capture of $\mathrm{OH}$ radicals, indirect effects are more and more prevented. A mathematical fit realized with the rational three-parameter function $(a+b \sigma) /(1+c \sigma)$ on the experimental data of SSB $=f(\sigma)$ at the constant (and highest used) dose of 88 Gy provides the following data: $a=2.4252, b=1.252610^{-7}, c=1.418010^{-6}$ with $R^{2}=0.9934$. Analysing the used fitting function at the limits, namely for $\sigma \rightarrow 0$ and $\sigma \rightarrow+\infty$ provides for zero scavenging capacity; SSB $=a=2.4252$, and for infinite scavenging capacity; SSB $\rightarrow b / c=0.088$ which yields a ratio (direct effects)/(indirect effects) $=0.038$, equivalent to $96.2 \%$ indirect effects. This value is in rather good agreement with $97.7 \%$ indirect effects (Tomita et al., 1995) determined using $\gamma$ irradiated frozen solutions $\left(-20^{\circ} \mathrm{C}\right.$, i.e. only direct effects arise) of pBR322 plasmid DNA from which the $D_{37}$ was compared to those of solutions kept at various temperatures ranging from -5 to $40{ }^{\circ} \mathrm{C}$ (i.e. where direct + increasing indirect effects take place).

We have repeated our protocol by using basic amino acids of arginine (Arg), histidine (His) and lysine (Lys) as well as Tris in the presence of pUC21 plasmid DNA. The hydroxyl radical scavenger reaction rate constants for the quoted amino acids are: $\mathrm{k}_{\mathrm{Arg}}=3.5 \times 10^{9} \mathrm{~L} \cdot \mathrm{mol}^{-1} \cdot \mathrm{s}^{-1}$ at $\mathrm{pH}=\sim 7$ (Scholes et al., 1965), $\mathrm{k}_{\text {His }}=4.8 \times 10^{9} \mathrm{~L} \cdot \mathrm{mol}^{-1} \cdot \mathrm{s}^{-1}$ at $\mathrm{pH}=7,5$ (Motohashi et Saito, 1993).and $\mathrm{k}_{\mathrm{Lys}}=3.5 \times 10^{8} \mathrm{~L} \cdot \mathrm{mol}^{-1} \cdot \mathrm{s}^{-1}$ at $\mathrm{pH}=6,6$ (Masuda et al.,1973). The results are presented in the Fig.7.

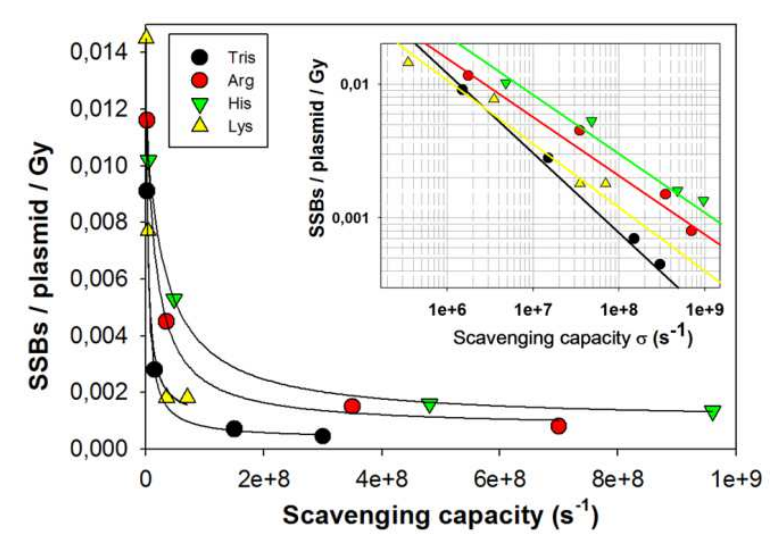

Figure 7: Experimentally determined damage rates of SSB per plasmid and per Gray (pUC21 with 3266 bp at a concentration of $10 \mathrm{ng} . \mathrm{\mu L}^{-1}$ ) versus scavenging capacity of Tris, Arg, His and Lys with concentrations 1, 10, 100 and $200 \mathrm{mM}$. The black full 
lines are fits based on the rational 3-parameters function $(a+b \sigma) /(1+c \sigma)$. The inset shows the same experimental data set but in a Log-Log coordinate system; the colour full-lines account for their respective linear regressions.

Applying the same analytical procedure as mentioned above, we extract estimates of the values of percentages of indirect effects, $\xi$ (\% I.E.). The fitting parameters and resulting ratios as well as the hydroxyl radical scavenger reaction rate constants are also presented in Table 1.

Table 1

Fitting parameters of the data presented in Fig. 7 relative to Tris, Arg, His and Lys, the corresponding percentages of indirect effects $(\xi)$.

\begin{tabular}{|c|c|c|c|c|c|}
\hline & $\mathbf{a}$ & $\mathbf{b}$ & $\mathbf{c}$ & $\mathbf{R}^{2}$ & $\xi$ (\% I. E.) \\
\hline Tris & 0.0126 & $9.185010^{-11}$ & $2.651310^{-7}$ & 0.9999 & $\mathbf{9 7 . 2}$ \\
\hline Arg & 0.0128 & $4.612910^{-11}$ & $6.233010^{-8}$ & 0.9987 & $\mathbf{9 4 . 2}$ \\
\hline His & 0.0115 & $2.864110^{-11}$ & $2.995610^{-8}$ & 0.9999 & $\mathbf{9 1 . 7}$ \\
\hline Lys & 0.0163 & $3.615010^{-10}$ & $3.680410^{-7}$ & 09987 & $\mathbf{9 4 . 0}$ \\
\hline
\end{tabular}

The value of $\xi_{\text {Tris }}=97.2 \%$ obtained herein using pUC21 plasmid (3266 bp) is very close (1\% variation) to the preceding value quoted above for Tris as a scavenger and determined with pBR322 plasmids (4363 bp), namely $\xi_{\text {Tris }}=96.2 \%$. This seems thus to confirm the validity of the applied procedure to determine $\xi$ values. In the whole, extreme $\xi$ values presented in Table 1 differ by 5.5\%; their average value being $94.3 \pm 2.3 \%$. Looking at the inset in Fig. 7 it appears unexpected that at the high scavenging capacities we observe a trend of SSB damage rates which increases in the order Tris, Lys, Arg, His as we may rather expect His, Arg, Tris, Lys according to the hydroxyl radical scavenger reaction rate constant values. Indeed, by scavenging $\mathrm{OH}$ radicals and thus preventing a part of indirect effects, the presence of scavenging species should decrease the value of the damage rates when $\mathrm{k}$ increases. If correct, such an observation may highlight the fact that additional indirect damages appear during the course of our experiments with Arg, Lys and His and those damages might not be imparted to the action of $\mathrm{OH}$ radicals. As described in details in one of our recent papers (Souici et al., 2016 and references therein) in which the special cases of Tris and Arg where studied and compared in details, additional damages might arise through side effects, namely radical transfer from arginine radicals directly to DNA. Such an unexpected effect can be explained by invoking the following pathway. Arginine and lysine have actually the natural propensity to be localized in the close vicinity of the DNA's phosphate moieties due to Van der Waals contacts, hydrogen bonds as well as water bridges (Luscombe et al., 2001) which constitute non-specific interactions but also inside the double-helix, thus forming specific interactions. As quoted by Luscombe and co-workers, arginine and lysine strongly favour guanine for specific interactions and 
largely account for the abundance of hydrogen-bond interactions with this base. It is thus likely that due to their probable localization inside the double-helix, those amino acids, when scavenging $\mathrm{OH}$ radicals, are themselves transformed in radicals and thus are able to transfer the radical to the DNA macromolecule. It is important here to note that as demonstrated by Stanton and coworkers (Stanton et al. 1993) and based on both X-ray and heavy-ion irradiations, Tris secondary radical attack do not appear to play a role in DNA damaging, even at scavenging capacities higher than the highest ones used in our present study. Furthermore, the radiolysis products of Arg, Lys and His have been analysed further to ${ }^{137} \mathrm{Cs}$ gamma-ray irradiation in the aqueous phase (Xu et al., 2003) and it was shown that those basic amino acids all form stable oxidation products with specific kinetics after having captured $\mathrm{OH}$ radicals. Interestingly, these authors have shown that His is oxidized following radiolysis to give a mixture of four different products through oxidative opening and addition of the imidazole ring. In addition, pulse radiolysis studies combined with spectroscopic analyses (Navaratnam and Parsons, 1998) have shown that the free radicals can be formed as well on the molecular chain as on the imidazole ring of His. This large variety of radiolysis products for histidine is in favour of the unexpected high DNA damage rate observed although His has low probability to be present inside the DNA double-helix (Luscombe et al., 2001) as compared to Arg and Lys. With its high scavenger reaction rate constant, it is indeed foreseeable that, within the high scavenging capacities used in this work, the numerous and various radical products formed by reaction of His with ${ }^{\circ} \mathrm{OH}$ are prone to transfer the radical to DNA (at $[\mathrm{His}]=200 \mathrm{mM}$, the ratio $[\mathrm{His}] /\left[\mathrm{PO}_{4}{ }^{-}\right]_{\mathrm{DNA}}>6000$ within our experimental conditions). Moreover, such an assertion can be reinforced by the fact that contrary to the value of $\mathrm{k}_{\text {His }}=4.8 \times 10^{9} \mathrm{~L} \cdot \mathrm{mol}^{-1} \cdot \mathrm{s}^{-1}$ at $\mathrm{pH}=7,5$ (Motohashi et Saito, 1993) we use in

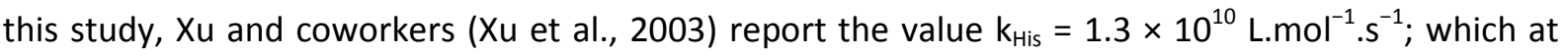
equal concentration of $\mathrm{Arg}$ and $\mathrm{His}$ might make His 3.7-times more effective at scavenging $\mathrm{OH}$ radicals than Arg. Interestingly, Milligan and coworkers have shown that the His rate constant for repair of DNA guanyl radicals is extremely low (Milligan et al., 2003) when compared to those of the five other most easily oxidized amino acids; namely cysteine, cystine, histidine, methionine, tryptophan and tyrosine. Lastly, it seems not useless here to mention that if side effects there are, their action on the statistical percentages of indirect effects $\xi$, measured within our experimental conditions remains within the range of $5.5 \%$ which is close to a rough estimate of the experimental uncertainty (typically a few \%).

\section{Conclusion}

In a first part of this paper we have summarized the most significant results which have been obtained by exposing dry nanometer-scaled layers of Dap-plasmid DNA complexes to LEEs in UHV. 
For the first time, an absolute cross-section for the loss of supercoiled topology was measured and this value is in good agreement with effective cross-sections determined by others. The fact that our drop-casted layers in which DNA is complexed with 1,3-diaminopropane did not charge and because they presented similar behaviors at various thicknesses when exposed to LEEs is in favor of some peculiar properties of those samples linked with the close environment of the double-helix. This was checked by inspecting ESD features of the layers. It was shown that there is indeed a noticeable difference, notably for the release identified at the mass ratio $17 / 16\left(\mathrm{OH}^{-} /\left(\mathrm{O}_{2}{ }^{-} / \mathrm{NH}_{2}{ }^{-}\right)\right)$, which highlights a different mechanism for the dissociative channel of the TNI when the phosphate groups of the DNA macromolecule are largely engaged in electrostatic interactions with amino moieties. This particular point will be checked in the near future by using layers of plasmid DNA complexed with basic amino acids (Arg, His, Lys) but also with short polypeptides rich in arginine and lysine, the two most abundant positively charged amino acids found in histone tails.

When exposed to AI K $\alpha$ USXs in air, the layers are mostly subjected to secondary photo-LEEs whose spectrum lies in the range [0-20 eV] with a maximum near to $2 \mathrm{eV}$. We find that with a thickness $>50$ $\pm 10 \mathrm{~nm}$, the DNA damage rate determined within the framework of plasmid DNA relaxation assay reach a plateau. Conversely at lower thicknesses, the damage rates follow a drastic decline indicating that the order of magnitude of the effective attenuation length of the photo-LEEs must be near to 11-16 nm in DNA kept under atmospheric conditions. This value is in good agreement with the rare data provided by others and which stems from computer simulations when dealing with DNA and from both experiments and calculations when dealing with water (the usual surrogate of DNA).

In order to go on further with experiments related to the very local biological effects of ionizing radiation secondaries we have developed a bench-top cold-cathode ultra-soft X-ray (USX) generator which enables small volumes of liquid samples to be exposed. In these experiments the local effects of radiation-induced DNA damages can be spatially reduced to some nanometers in water, by using specific ROS scavengers. By doing this over a wide range of $\mathrm{OH}$ radical scavenging capacities, the damages rates expressed versus scavenging capacities exhibit a vertical asymptote at the low scavenging capacities while an horizontal asymptote is observed at the high scavenging capacities. This separation on the one side of direct effects and on the other side of (direct + indirect effects) enables us to evaluate the proportion of indirect effects arising in water under USX irradiation at 1.5 keV. With Tris as a ${ }^{\circ} \mathrm{OH}$ scavenger we found $96.2 \%$ and $97.2 \%$ indirect effects in two different series of experiments; while when using basic amino acids as scavengers, the proportion of indirect effects dropped down to $91.7 \%$ with histidine. The average value taken over all the 5 experimental data sets is $94.7 \pm 2.1 \%$ indirect effects in water under standard conditions. 


\section{Acknowledgments}

This work was partially supported by a PROFAS French-Algerian support (Ph. D. of N. Ounoughi and M. Souici) and by a grant from the Iraqi embassy (Ph. D. of T. T. Khalil). A part of this work also was financed by the Canadian Institutes of Health Research via Grant No. MOP 86676. The authors are particularly indebted to Pr Léon Sanche and Dr Pierre Cloutier from the University of Sherbrooke who always generously hosted our experiments dealing with LEEs in their laboratory. The authors would like to thank the following students who have been participating to some parts of the presented studies, namely Ouiza Manseur, Nabil Ounoughi, Mounir Souici, Talat Tariq Khalil and Baptiste Taillefumier. 


\section{References:}

Aflatooni K. , Scheer A. M., and P. D. Burrow P. D., 2006. Total dissociative electron attachment cross sections for molecular constituents of DNA. J. Chem. Phys. 125, 054301.

Alizadeh E., Sanz A. G., García G., and Sanche L., 2013. Radiation Damage to DNA: The Indirect Effect of Low Energy Electrons. J. Phys. Chem. Lett., 4(5), 820-825.

Barrios R., Skurski P., and Simons J. 2002.Mechanism for Damage to DNA by Low-Energy Electrons. J. Phys. Chem. B, , 106, 7991-7994.

Bethe H. A., 1933. (V) "Quantenmechanik der Ein- und Zweielectronenprobleme." Handbuch der Physik, 24, 1. Berlin: Springer.

Boulanouar, O., Khatyr, A., Herlem, G., Palmino, F., Sanche, L., Fromm, M., 2011. Soft adsorption of densely packed layers of DNA-plasmid - 1,3-diaminopropane complexes onto highly oriented pyrolytic graphite designed to erode in water. J. Phys. Chem. C, 115 (43), 21291-21298.

Boulanouar O., Fromm M., Bass A. D., Cloutier P., and Sanche L., 2013a. Absolute cross section for loss of supercoiled topology induced by $10 \mathrm{eV}$ electrons in highly uniform /DNA/1,3-diaminopropane films deposited on highly ordered pyrolitic graphite. J. Chem. Phys. 139, 055104.

Boulanouar O., Fromm M., Mavon C., Cloutier P., Sanche L., 2013b. Dissociative Electron Attachment to DNA-Diamine thin films: Impact of the DNA close environment on the $\mathrm{OH}$ - and O- Decay Channels. J. Chem. Phys. 139, 055101.

Boudaiffa B., Cloutier P., Hunting D., Huels M. A. and Sanche L., 2000. Resonant formation of DNA strand breaks by low-energy ( 3 to $20 \mathrm{eV}$ ) electrons. Science 287, 1658-60.

Boudaiffa B., Cloutier P., Hunting D., Huels M. A. and Sanche L., 2002. Cross sections for low-energy (10-50 eV) electron damage to DNA. Radiat. Res., 157, 227-34.

Brun, E., Cloutier, P., Sicard-Roselli, C., Fromm, M., Sanche, L., 2009. Damage induced to DNA by lowenergy (0-30 eV) electrons under vacuum and atmospheric conditions. J. Phys. Chem. B, 113 (29), 10008-10013. 
Cai Z., Dextraze M-E, Cloutier P., Hunting D., Sanche L., 2006. Induction of strand breaks by lowenergy electrons (8-68 eV) in a self-assembled monolayer of oligonucleotides: effective cross sections and attenuation lengths. J. Chem. Phys., 124, 024705.

Cobut, V., Frongillo, Y., Patau, J.P., Goulet, T., Fraser, M., Jay-Gerin, J., 1998. Monte Carlo simulation of fast electron and proton tracks in liquid water - I. physical and physicochemical aspects. Radiat. Phys. Chem., 51, 3, 229-243.

Fulford J. ,Bonner P., Goodhead D. T., Hill M. A. , and O'Neill P., 1999. Experimental Determination of the Dependence of $\mathrm{OH}$ Radical Yield on Photon Energy: A Comparison with Theoretical Simulations. J. Phys. Chem. A, Vol. 103, No. 51, 1999.

Emfietzoglou D., Kyriakou I., Abril I., Garcia-Molina R., Petsalakis I.D., Nikjoo H., Pathak A., 2009. NIM B, 267, 45-52.

Emfietzoglou D., Kyriakou I., Abril I., Garcia-Molina R., and Nikjoo H., 2012. Inelastic scattering of lowenergy electrons in liquid water computed from optical-data models of the Bethe surface. Int. J. Radiat. Biol. 88, 22.

Henke B. L., Smith J. A. and Attwood D. T., 1977. 0.1 - $10 \mathrm{keV}$ x-ray-induced electron emissions from solids-Models and secondary electron measurements. J. Appl. Phys., 48 (5), 1852-1866.

Goodhead D. T., Thacker J., 1977. Inactivation and mutation of cultured mammalian cells by aluminium characteristic ultra-soft X-rays. I. Properties of aluminium X-rays and preliminary experiments with Chinese hamster cells. Int. J. Radiat. Biol., 31(6):541-559.

Groetz J. E., Ounoughi N., Mavon C., Belafrites A., Fromm M., 2014. Conception and realization of a parallel-plate free-air ionization chamber for the absolute dosimetry of an ultrasoft X-ray beam, Review of Scientific Instruments, 85, 83304.

Hicks M. and Gebicki J. M., 1986. Rate constants for reaction of hydroxyl radicals with Tris. Tricine and Hepes buffers. FEBS Lett. 199(1), 92-94. 
Imlay J. A., Chin S. M., Linn S., 1988. Toxic DNA damage by hydrogen peroxide through the Fenton reaction in vivo and in vitro. Science, 240 (4852), 640-642.

Kielkopf, C. L.; Ding, S.; Kuhn, P.; Rees, D. C., 2000. Conformational flexibility of B-DNA at 0.74 A resolution: d(CCAGTACTGG)(2). J. Mol. Biol. 296, 787-801.

Korolev N., Lyubartsev A. P., Laaksonen A., Nordenskiöld L., 2004a. Molecular dynamics simulation study of oriented polyamine-and Na-DNA: Sequence specific interactions and effects on DNA structure. Biopolymers, 73 (5), 542-555.

Korolev N., Lyubartsev A. P.; Laaksonen A.; Nordenskiöld L., 2004b. A molecular dynamics simulation study of polyamine-and sodium-DNA. Interplay between polyamine binding and DNA structure. Eur. Biophys. J. 33 , 671-682.

Li X, Sevilla MD, Sanche L., 2003. Density functional theory studies of electron interaction with DNA: can zero eV electrons induce strand breaks? J. Am. Chem. Soc. 2003, 125(45), 13668-9.

Li Z., Cloutier P., Sanche L. and Wagner J.R. 2011. Low-energy electron damage in a trinucleotide containing 5-Bromouracil, J. Phys. Chem. B. 115, 13668

Lomax M. E., Folkes L. K., O'Neill P., 2013. Biological consequences of radiation-induced DNA damage: relevance to radiotherapy. Clin Oncol (R Coll Radiol), 25(10), 578-85.

Luscombe N. M., Laskowski R. A., Thornton J. M., 2001. Amino acid-base interactions: a threedimensional analysis of protein-DNA interactions at an atomic level. Nucl Acids Res, 29(13),28602874.

Masuda T., Nakano S., Kondo M. J., 1973. Rate constants for the reactions of OH radicals with the enzyme proteins as determined by the p-nitrosodimethylaniline method. J. Radiat. Res. 14, 339-345.

Michaud M., Cloutier P., and Sanche L.. 1991. Low-energy electron-energy-loss spectroscopy of amorphous ice: Electronic excitations. Phys. Rev. A, 44, 5624.

Milligan J. R., Aguilera J. A., Ly A., Tran N. Q., Hoang O. and Ward J. F., 2003. Repair of oxidative DNA damage by amino acids. Nucleic Acids Research, 31(21), 6258-6263. 
Motohashi N.and Saito Y., 1993. Competitive measurement of rate constants for hydroxykl radical reactions using radiolytic hydroxylation of benzoate. Chem. Pharm. Bull. 41, 1842-1845.

Navaratnam S. and Parsons B. J., 1998. Reduction potential of histidine free radicals : a pulse radiolysis study. J. Chem. Soc., Faraday Trans., 94(17), 2577-2581.

Orlando T. M., Yanfeng Chen D. O. and Aleksandrov A. B., 2008. Low-energy electron diffraction and induced damage in hydrated DNA. J. Chem. Phys., 128, 195102.

Ounoughi N., Mavon C., Belafrites A., Groetz J. E., Fromm M., 2013. Beam characterization of a lab bench cold cathode ultra-soft X-ray generator, NIM B, 305, 61-66.

Ounoughi N., Mavon C., Belafrites A., Fromm M., 2015. Spatial Distribution of Air Kerma Rate and Impact of Accelerating Voltage onthe Quality of an Ultra Soft X-ray Beam generated by a Cold Cathode Tube in Air. Radiat. Meas., 80, 23-28.

Panajotovic R., Martin F., Cloutier P., Hunting D., Sanche L., 2006. Effective cross sections for production of single-strand breaks in plasmid DNA by 0.1 to $4.7 \mathrm{eV}$ electrons. Radiat. Res., 165(4), 452-9.

Powell C. J. and Jablonski A. 2002. Electron effective attenuation lengths for applications in Auger electron spectroscopy and x-ray photoelectron spectroscopy. Surf. Interface Anal., 33, 211 - 229.

Rezaee M., Cloutier P., Bass A. D., Michaud M., Hunting D. J., and Sanche L., 2012. Absolute cross section for low-energy-electron damage to condensed macromolecules: A case study of DNA. Phys. Rev. E, 86, 031913.

Scholes G., Shaw P., Willson R.L., Ebert M., 1965. In: Pulse Radiolysis, Ebert, M.; Keene, J.P.; Swallow, A.J.; Baxendale, J.H. (eds.), Academic Press, New York, 151-64.

Śmiałek M.A., Balog R., Jones N.C., Field D., Mason N.J., 2010. Preparation of DNA films for studies under vacuum conditions. The influence of cations in buffer solutions. Eur. Phys. J. D, 60, 31-36. 
Souici M., Khalil T. T., Boulanouar O., Belafrites A., Mavon C., Fromm M., 2016. DNA strand break dependence on Tris and arginine scavenger concentrations under ultra-soft X-ray irradiation: the contribution of secondary arginine radicals. Radiat. Env. Biophys., 55(2), 215-228.

Spotheim-Maurizot M., Ruiz S., Sabattier R. and Charlier M., 1995. Radioprotection of DNA by Polyamines. Int.J. Radiat. Biol., 68, $571-577$.

Spotheim-Maurizot M, Charlier M, Sabattier R. DNA radiolysis by fast neutrons. Int J Radiat Biol. 1990;57:301-13.

Stanton J., Taucher-Scholz G., Schneider M., Heilmann J., Kraft G., 1993. Protection of DNA from high LET radiation by two $\mathrm{OH}$ radical scavengers, tris (hydroxymethyl) aminomethane and 2mercaptoethanol. Radiat. Environ. Biophys., 32:21-32.

Su C., J., Liu Y. C., Chen H. L., LiY. C., Lin Y. K., Liu W. L., and Hsu C. S., 2007. Two-Dimensional Densely Packed DNA Nanostructure Derived from DNA Complexation with a Low-Generation Poly(amidoamine) Dendrimer. Langmuir, 23, 975-978

Suzuki Y. I., Nishizawa K., Kurahashi N., and Suzuki T., 2014. Effective attenuation length of an electron in liquid water between 10 and 600 eV. Phys. Rev. E., 20, 010302(R).

Tan Z., Xia Y., Liu X., Zhao M., Ji Y., Li F., Huang B., 2005. Electron inelastic interactions in bioorganic compounds in the energy range of 20-10 $000 \mathrm{eV}$. Appl. Phys. A, 81, 779-786.

Tanuma S., Powell C.J. and Penn D. R., 1993. Calculations of electron inelastic mean free paths. V. Data for 14 organic compounds over the 50-2000 eV range. Surface and Interface Analysis. 21, 165176.

Tomita H., Kai M., Kusama T., Aoki Y., 1995. Strand break formation in plasmid DNA irradiated in aqueous solution: effect of medium temperature and hydroxyl radical scavenger concentration. J. Radiat. Res., 36(1), 46-55.

Tougaard S., 2013. Validity of automated x-ray photoelectron spectroscopy algorithm to determine the amount of substance and the depth distribution of atoms. J. Vac. Sci. Technol. A, 31, 3. 
Uehara S. and Nikjoo H., 2006. Monte carlo simulation of water radiolysis for low-energy charged particles. J. Radiat. Res., 47(1), 69-81.

Yamaguchi H., Uchihori Y., Yasuda N., Takada M., Kitamura H., 2005. Estimation of Yields of OH Radicals in Water Irradiated by Ionizing Radiation. J. Radiat. Res., 46 (3), 333-341.

Wang J., 2001. On-Demand Electrochemical Release of Nucleic Acids. Electroanalysis 2001, 13 (8-9), 635-638.

Watanabe R. and Saito K., 2002. Monte Carlo simulation of strand-break induction on plasmid DNA in aqueous solution by monoenergetic electrons. Radiat. Environ. Biophys., 41, 207-215.

Xu G., Takamoto K., and Chance M. R., 2003. Radiolytic Modification of Basic Amino Acid Residues in Peptides: Probes for Examining Protein-Protein Interactions. Anal. Chem. 75, 6995-7007.

Zheng Y., Cloutier P., Hunting D. J., Sanche L., and Wagner J. R., 2005. Chemical basis of DNA sugarphosphate cleavage by low-energy electrons. J. Am. Chem. Soc. 127, 16592. 